\title{
MOLLUSC SPECIES PROTECTED IN POLAND AND THREATENED IN EUROPE RECORDED IN STEPNICA RIVER (NW POLAND)
}

\author{
Małgorzata Raczyńska' ${ }^{1}$ Juliusz C. Chojnacki ${ }^{1}$, Monika Hałupka ${ }^{1}$ \\ 1 Department of Marine Ecology and Environmental Protection, Faculty of Food Sciences and Fisheries, West \\ Pomeranian Technological University in Szczecin, Kazimierza Królewicza 4, 71-550 Szczecin, Poland, e-mail: \\ malgorzata.raczynska@zut.edu.pl; juliusz.chojnacki@zut.edu.pl
}

Received: 2014.05 .20

Accepted: 2014.08.05

Published: 2014.10.07

\begin{abstract}
In the course of the study two bivalve species protected in Poland were found in the river Stepnica: Sphaerium solidum and Sphaerium rivicola. Moreover, the study material collected from the river contained gastropod and bivalve specimens representing the following species from the IUCN Red List of Threatened Species: Theodoxus fluviatilis, Pisidium henslowanum, Pisidium casertanum and Pisidium pseudosphaerium.
\end{abstract}

Keywords: Bivalvia, Gastropoda, threatened species, protected species.

\section{INTRODUCTION}

Molluscs are the only group among the numerous groups of animals comprising 130000 species distributed all over the world which inhabit both aquatic and terrestrial environments. Representatives of two taxonomic classes of the Mollusca live in freshwater environments, namely the Gastropoda (slugs and snails) and the Bivalvia [Jura 2007]. As they are not particularly mobile and often even sedentary animals (mainly in the case of bivalves), they are reliable longterm indicators of local pollution, understood as a sum of biotic and abiotic influences in environment [Protasowicki \& Niedźwiecki 1995]. For instance, it is thanks to molluscs that periodical discharge of toxic wastewater is possible to detect [Chojnacki 1998]. The ability of molluses to serve as pollution indicators allows for evaluating a relative level of water contamination with toxic substances, assuming that concentrations of these substances in mollusc tissues are proportional to their concentrations in water [JurkiewiczKarnkowska 1998，2003，2004，2011, Oertel 1998]. Therefore, molluscs have proved particularly useful as bioindicators of water contamination with toxic substances and acidization of environment. They are also important for so-called emergency population warnings, being used for detection of unfavorable changes in water quality, for instance in waterworks systems [JurkiewiczKarnkowska 1998, 2004].

Unfortunately, progressively increasing pollution of aquatic ecosystems, caused mainly by human activity, contributes to a drop in the abundance of this group of invertebrates. Presently, several mollusc species are threatened with extinction and many species are legally protected. Therefore, conducting faunistic studies on this group of invertebrates in Poland is recommended, especially in regions where little is known about native mollusc fauna (e.g. in small water courses of Pomerania). Such studies will not only allow to make a list of areas where protected species of freshwater molluscs occur, but will also facilitate undertaking appropriate measures to protect these species.

\section{MATERIAL AND METHODS}

Mollusc material discussed in the present study was collected at monthly intervals during the period of research on macrobenthic fauna conducted from 21 December 2004 to 12 December 2006. The material was collected in the upper reaches of the river, using a bottom scraper, at 
four research stations along a river stretch situated $10 \mathrm{~km}$ away from the headstreams in the neighborhood of the settlement of Wisławie, as far as the town of Maszewo (Figure 1). The collected material was transferred to a laboratory, sifted through $0.45 \mathrm{~mm}$ mesh sieves and preserved with $70 \%$ buffered alcohol. The samples prepared in this way were arranged according to systematic groups and then qualitative identification was conducted. Detailed taxonomic identification of the molluscs was based on conchological features used in the studies by Piechocki [1979] and Piechocki \& Dyduch-Falniowska [1993].

\section{RESULTS}

Malacofauna of the river Stepnica was represented by 3 genera and 14 species of the Mollusca (Table 1), and its abundance in the years 2004-2006 amounted to 332 individuals. The most diverse taxonomically and at the same time the most abundant fauna of the Mollusca was found at the research station no. 2, situated in the town of Maszewo. At the remaining stations only representatives of the Gastropoda were recorded; they were encountered in the highest numbers at the research station no. 3 , in the town of Radzanek, whereas only two gastropod species were recorded at the station no. 1 (Wisławie), and only one at the station no. 4 (Maszewo) (Table 1).

Among the recorded molluscs there were both freshwater species common in Poland and protected species, as well as species threatened with extinction in Poland and in Europe. The species threatened with extinction in Europe found in the river Stepnica included one gastropod species: Theodoxus fluviatilis (12 individuals), and three bivalve species: Pisidium henslowanum (37 individuals), Pisidium casertanum (42 individuals) and Pisidium pseudosphaerium (22 individuals). Furthermore, taxonomic composition of the Bivalvia in the river Stepnica included also two species protected in Poland: Sphaerium solidum and Sphaerium rivicola, represented by 16 and 2 individuals respectively (Table 1).

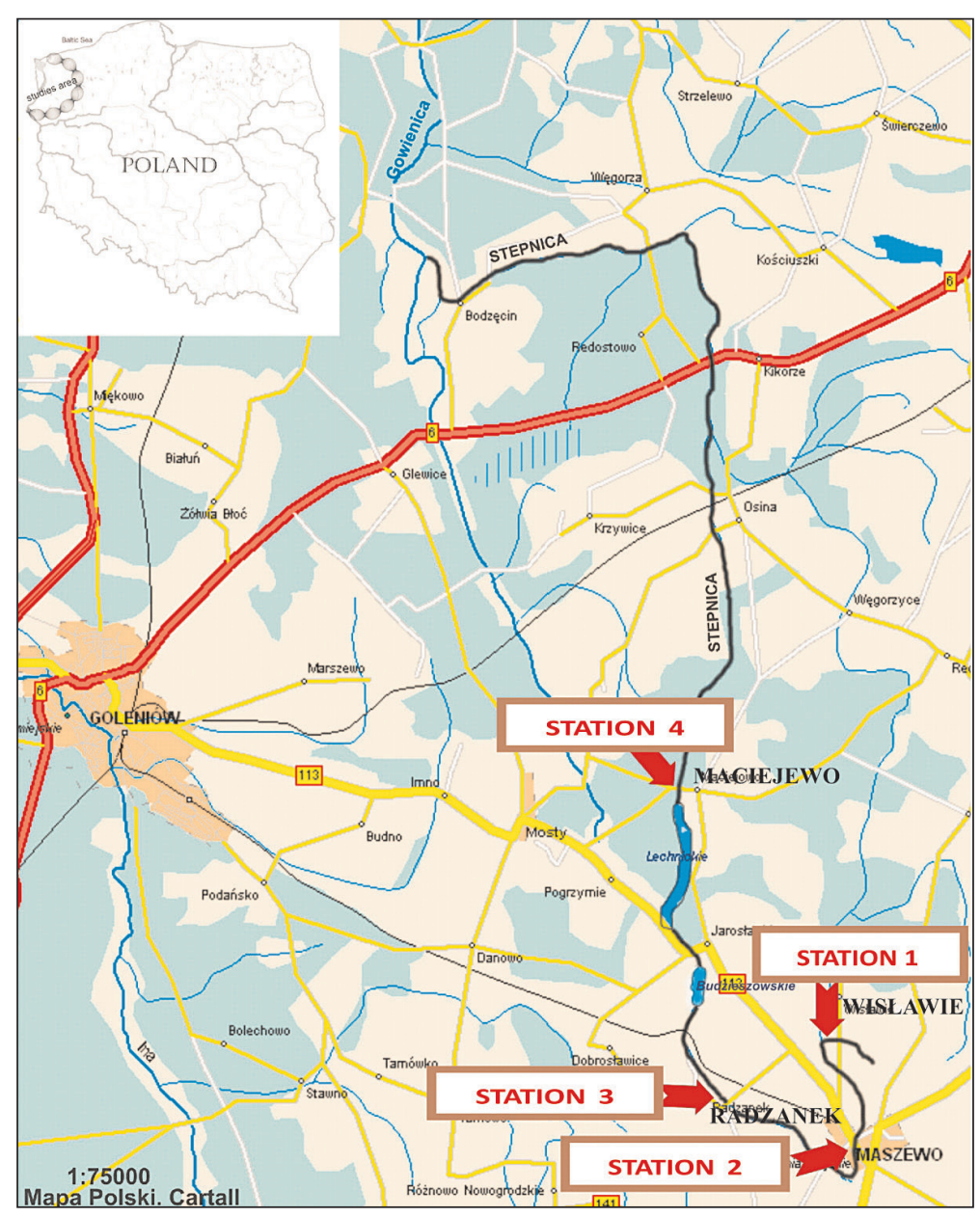

Figure 1. Location of research stations 
Table 1. Average abundance of gastropods and bivalves in the river Stepnica in the years 2004-2006

\begin{tabular}{|c|c|c|c|c|c|}
\hline & Station 1 & Station 2 & Station 3 & Station 4 & Total \\
\hline \multicolumn{6}{|c|}{ Gastropoda } \\
\hline Theodoxus fluviatilis & & 8 & 4 & & 12 \\
\hline Valvata piscinalis & & & 42 & & 42 \\
\hline Bithynia tentaculata & 6 & 15 & & & 21 \\
\hline Lymnaea stagnalis & & & 2 & & 2 \\
\hline Radix peregra & & 4 & 1 & & 5 \\
\hline Planorbis carinatus & & 15 & 21 & 3 & 39 \\
\hline Planorbarius corneus & 14 & 1 & 1 & & 16 \\
\hline Anisus sp. & & & 1 & & 1 \\
\hline \multicolumn{6}{|c|}{ Bivalvia } \\
\hline Sphaerium sp. & & 2 & & & 2 \\
\hline Sphaerium rivicola & & 2 & & & 2 \\
\hline Sphaerium solidum & & 16 & & & 16 \\
\hline Pisidium sp. & & 8 & & & 8 \\
\hline Pisidium amnicum & & 13 & & & 13 \\
\hline Pisidium casertanum & & 42 & & & 42 \\
\hline Pisidium henslowanum & & 37 & & & 37 \\
\hline Pisidium milium & & 52 & & & 52 \\
\hline Pisidium pseudosphaerium & & 22 & & & 22 \\
\hline
\end{tabular}

\section{DISCUSSION}

The upper reaches of the river Stepnica, where the study was conducted, were characterized by specific environmental conditions. According to Raczyńska et al. [2013], from the point of view of hydromorphological quality, ecological condition of the four research stations on the river Stepnica ranged from poor to bad and did not meet standards of the Water Framework Directive. This was due to a low diversity of natural morphological elements and a considerable amount of alterations caused by human activity taking place on the river in the past. A hydrochemical study of the river revealed that its ecological condition was less than good, especially at the research station no. 3, in the town of Radzanek, and at the research station no. 4 , in the town of Maciejewo. During the studies, hydrogen sulfide was detected at the Radzanek station (no. 3); the presence of the compound had a negative impact on the river biocenosis [Raczyńska et al. 2013]. The impact of these facts on the molluscs was noted during the studies, since the most abundant population of these animals was found at the research station no. 2 in the town of Maszewo, where water quality was the highest. It was also the only station where the presence of bivalves was recorded in the course of the studies (Table 1).
The two bivalve species recorded solely at the Maszewo research station (no. 2), i.e. the solid orb mussel Sphaerium solidum [Normand 1844] and the river orb mussel Sphaerium rivicola [Lamarck 1818] are on the list of animals under strict protection in Poland, pursuant to the Ordinance of the Minister of Environment on the protection of animal species [Journal of Laws of the Republic of Poland No. 237, item 1419, of 12 October 2011]. Furthermore, on the Polish list of threatened species, Sphaerium solidum is classified as EN (Endangered), whereas on the IUCN Red List of Threatened Species it is put under the category NT (Near Threatened) [Dyduch-Falniowska \& Zając 2004, Van Damme et al. 2012].

S. solidum is a species encountered in some rivers in northern Poland, which in the 19th and 20th centuries was relatively abundant in larger Polish rivers, especially in the middle and lower reaches of the Vistula and the Oder [Piechocki \& Dyduch-Falniowska 1993, Dyduch-Falniowska \& Zając 2004]. In more recent times, the solid orb mussel has been recorded in merely 10 localities throughout Poland [Dyduch-Falniowska \&i Zając 2004], and the fact of its occurrence in the Stepnica has expanded its range in the country. The occurrence of the solid orb mussel and the river orb mussel in the river Stepnica at the Maszewo station may be connected with the presence of sub- 
strates preferred by the species. S. solidum prefers sandy bottoms with a slight admixture of mud, or even with coarse-grained sand, while Sphaerium rivicola prefers rivers with muddy sediments and low water current [Wolff 1970]. Exactly this type of sandy and muddy substrate was present at the station in question. S. solidum is an exceptionally reophilous and oxygen-loving species [Glöer et al. 1992], and its preferred habitats are deep sections of rivers and channels [Van Damme et al. 2011], rather unlike its habitats in the river Stepnica. Although the amount of dissolved oxygen at the Maszewo station was characteristic for the first water quality class in Poland [Raczyńska et al. 2013], such characteristics of the river as the flow (imperceptible) and average depth of about $20 \mathrm{~cm}$ during the study period did not provide optimal conditions for the development of the discussed species. Even though Sphaerium rivicola has a very low tolerance to pollution, it has sometimes been encountered in a slightly polluted river current [Wolff 1970, Van Damme et al. 2011]. Water quality at the station no. 2 ranged between the first and second class, but the concentrations of total suspended solids, as well as nitrogen and phosphorus compounds indicated that the actual water quality was less than good [Raczyńska et al. 2013], which might limit population abundance of the discussed species.

The remaining molluscs included in the IUCN Red List of Threatened Species, i.e. Theodoxus fluviatilis, Pisidium henslowanum, Pisidium casertanum and Pisidium pseudosphaerium belonged to the category LC (Least Concern). Although disturbances caused by human activity and local water pollution are potential threats to these species, presently there is no need to undertake any protective measures [Categories \& Criteria, Killeen 2011, Cordeiro \& Killeen 2011, Budha 2012, Kebapçı \& Van Damme 2012]. All of the above mentioned species are common in their preferred habitats in Polish waters. So far, no declining tendency has been observed with respect to their populations in Poland and they have not been classified under any category of threatened Polish species.

\section{CONCLUSIONS}

Unexpectedly, in the river Stepnica, a minor water course in Western Pomerania, strongly altered by human activity and vulnerable to pollu- tion, mollusc species have been found. They are not only legally protected in Poland but also featured on the IUCN Red List of Threatened Species. The results of the present study lead to a conclusion than in spite of locally occurring ecological disasters, populations of natural inhabitants are still present in the studied river and they may easily and dynamically expand their ecological structures, thus lead to increased biodiversity.

\section{Acknowledgements}

The authors would like to thank Professor Lucjan Agapow for his assistance with mollusc identification.

\section{REFERENCES}

1. Budha P.B., 2012. Pisidium casertanum. In: IUCN Red List of Threatened Species. Version 2013.2, www.iucnredlist.org

2. Categories \& Criteria: (version 3.1) http://www.iucnredlist.org/static/categories_criteria_3_1\#categories

3. Chojnacki J.C., 1998. Podstawy ekologii wód. Wyd. Akad. Roln. Szczecin, 1-177.

4. Cordeiro J., Killeen I., 2011. Pisidium henslowanum. In: IUCN Red List of Threatened Species. Version 2013.2, www.iucnredlist.org

5. Dyduch-Falniowska A., Zając K., 2004. W: Polska czerwona księga zwierząt - bezkręgowce. Wersja 2004-2009, http://www.iop.krakow.pl/pckz/opis. asp?id $=126 \& \mathrm{je}=\mathrm{pl}$

6. Journal of Laws of the Republic of Poland No. 237, item 1419, of 12 October 2011 (Dz.U. $\mathrm{Nr} 237$, poz. 1419 z dnia z dnia 12 października 2011 r.): Rozporządzenie Ministra Środowiska z dnia 12 października 2011 r. w sprawie ochrony gatunkowej zwierząt.

7. Glöer P., Meier-Brook C., Ostermann O., 1992. Süßwassermollusken. Aufl. Hamburg, DJN, 5, 81.

8. Jura Cz., 2007. Bezkręgowce. Podstawy morfologii funkcjonalnej, systematyki i filogenezy PWN.

9. Jurkiewicz-Karnkowska E., 1998. Reakcje mięczaków na zanieczyszczenie środowisk wodnych metalami ciężkimi i możliwości ich wykorzystania w bioindykacji. Wiad. Ekol. 44(3), 217-234.

10. Jurkiewicz-Karnkowska E., 2003. Application possibilities of snails from the ge-nus Lymnaea as bioindicators of heavy metals. Ekologija 2, 28-32.

11. Jurkiewicz-Karnkowska E., 2004. Malacocoenoses of large lowland dam reservoirs of the Vistula River basin and selected aspects of their function. Folia Malacologica 12, 1-56. 
12. Jurkiewicz-Karnkowska E., 2011. Accumulation of heavy metals in selected Gastropod species lower Bug river and its floodplain water bodies. Ochr. Środ. Zas. Nat. Nr 48, 316-323.

13. Kebapçı U., Van Damme D., 2012. Theodoxus fluviatilis. In: IUCN Red List of Threatened Species. Version 2013.2, www.iucnredlist.org.

14. Killeen I., 2011. Pisidium pseudosphaerium. In: IUCN Red List of Threatened Species. Version 2013.2, www.iucnredlist.org

15. Oertel N., 1998. Molluscs as bioindicators of heavy metals in a side-arm system of the River Danube disturbed by engineering activity. Verh. Internat. Verein. Limnol. 26, 2120־2124.

16. Piechocki A., 1979. Mięczaki (Mollusca). Ślimaki (Gastropoda). Fauna Słodkowodna Polski, 7. PWN, Warszawa-Poznań.

17. Piechocki A., Dyduch-Falniowska A., 1993. Mięczaki (Mollusca). Małże (Bivalvia). Fauna
Słodkowodna Polski, zesz. 7 A. PWN, Warszawa.

18. Protasowicki M., Niedźwiecki E., 1995. Zanieczyszczenie osadów dennych ujścia Odry metalami ciężkimi w świetle wieloletnich badań. W: Europejski ład ekologiczny (red: Chojnacki J., Pałyga J.E). Bibl. Fund. A.F. Modrzewskiego 14, Folia humanitaties 6, 122-127.

19. Raczyńska M., Machula S., Grzeszczyk-Kowalska A., 2013. Stan ekologiczny rzeki Stepnicy (Pomorze Zachodnie). Inżynieria Ekologiczna (Ecological Engineering), 35, 46-59.

20. Van Damme D., Killeen I., von Proschwitz T., 2012. Sphaerium solidum. In: IUCN Red List of Threatened Species. Version 2013.2, www.iucnredlist.org

21. Wolff W.J., 1970. The Mollusca of the estuarine region of the rivers Rhine, Meuse and Scheldt in relation to the hydrography of the area. IV. The genus Sphaerium. Basteria 34(3-4), 75-90. 